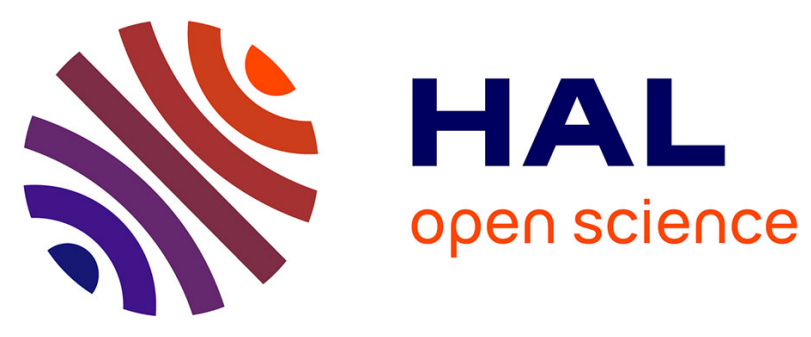

\title{
Balance between (de)hydrogenation and acid sites: comparison between sulfide-based and Pt-based bifunctional hydrocracking catalysts
}

Gerhard D Pirngruber, Sylvie Maury, Antoine Daudin, Pierre y Alspektor, Christophe Bouchy, Emmanuelle Guillon

\section{To cite this version:}

Gerhard D Pirngruber, Sylvie Maury, Antoine Daudin, Pierre y Alspektor, Christophe Bouchy, et al.. Balance between (de)hydrogenation and acid sites: comparison between sulfide-based and Pt-based bifunctional hydrocracking catalysts. Industrial and engineering chemistry research, 2020, 59 (28), pp.12686-12695. 10.1021/acs.iecr.0c01680 . hal-02953484

\section{HAL Id: hal-02953484 \\ https://hal-ifp.archives-ouvertes.fr/hal-02953484}

Submitted on 30 Sep 2020

HAL is a multi-disciplinary open access archive for the deposit and dissemination of scientific research documents, whether they are published or not. The documents may come from teaching and research institutions in France or abroad, or from public or private research centers.
L'archive ouverte pluridisciplinaire HAL, est destinée au dépôt et à la diffusion de documents scientifiques de niveau recherche, publiés ou non, émanant des établissements d'enseignement et de recherche français ou étrangers, des laboratoires publics ou privés. 


\title{
Balance between (de)hydrogenation and acid sites:
}

\author{
comparison between sulfide-based and Pt-based
}

\section{bifunctional hydrocracking catalysts}

Gerhard D. Pirngruber*, Sylvie Maury, Antoine Daudin, Pierre Y. Alspektor, ${ }^{\dagger}$ Christophe Bouchy, Emmanuelle Guillon

IFP Energies nouvelles, Site of Lyon, Rond-Point de l'échangeur de Solaize, BP 3, 69360 Solaize, France.

KEYWORDS. USY, hydroisomerization, hydrocracking, hexadecane, $\mathrm{MoS}_{2}$, inhibition

ABSTRACT. Most industrial hydrocracking catalysts contain metal sulfides. It is commonly accepted that sulfide-based bifunctional hydrocracking catalysts are less well balanced than Ptbased catalysts, because of their weak (de)hydrogenation activity. However, the difference in catalytic performances between the two catalysts has never been quantified. In the present work, hydrocracking catalysts were prepared by shaping the USY zeolite CBV720 with alumina binder. Acidity was varied by changing the USY content. The extudates were impregnated either with platinum or with nickel-molybdenum-phosphate and evaluated in the hydroconversion of nhexadecane. In the absence of $\mathrm{NH}_{3}$, NiMo sulfide was unable to supply the acid sites and to avoid cracking reactions. Cracking became the dominating pathway. In the presence of $\mathrm{NH}_{3}$, 
only a tiny fraction of the acid sites was vacant. This allowed the NiMo sulfide catalysts to become fairly well balanced, if the zeolite loading was low. Increasing zeolite loading led to a deviation from ideality. Pt catalysts were, with one single exception (at very high USY content), always balanced, even in the absence of $\mathrm{NH}_{3}$.

\section{Introduction}

Hydrocracking catalysts are bifunctional systems, conjugating an acid and a metallic function. The metal sites are responsible for dehydrogenation of saturated reactants to olefins, which can then be more easily activated on the acid sites to be further cracked or isomerized. The metallic function hydrogenates the olefins produced by cracking or isomerization reactions back to paraffins. The metal also prevents deactivation by coking.

For model catalysts, i.e. Pt-zeolites, the balance between the two functions has been extremely well described. The seminal works on hydroisomerization and hydrocracking of $n$-alkanes, for example from Guisnet's group, ${ }^{1,2}$ show that an increase in the metal loading increases the activity of the catalyst until a plateau is reached. The plateau is supposed to correspond to the dehydrogenation activity, which establishes thermodynamic equilibrium between paraffin reactant and its corresponding olefin.

The selectivity to isomerization vs. cracking products has an even stronger dependence on the metal loading. If the metal loading is too low, then the intermediates of isomerization reactions have a higher probability of undergoing consecutive cracking reactions, instead of being hydrogenated to iso-paraffins. ${ }^{3}$ The selectivity for isomerization products increases with increasing metal loading up to a maximum, which corresponds to the intrinsic selectivity of the zeolite. Yet, metal loading is not a sufficient criterion. The metal must also be well dispersed and its location must allow fast diffusion of intermediates between metal and acid sites (intimacy 
criterion of Weisz). ${ }^{4-6}$ The initial paradigm that the metal sites must be as close as possible to the acid sites has recently been revisited and refined..$^{7-9}$

Once the plateau of activity and selectivity is reached we speak about an ideal or balanced catalyst (acid catalyzed reactions become the limiting step). Catalyst activity and selectivity only depends on the properties of the acid sites and shape selectivity effects, but not on the metal function anymore. ${ }^{10}$

Pt has a very high (de)hydrogenation activity and by careful Pt deposition (ion exchange in the presence of competitors usually works best ${ }^{11}$ ) most zeolite catalysts can be balanced. However, industrial catalysts used for the hydrocracking of heavy oil fractions do not contain $\mathrm{Pt}$, but $\mathrm{Ni}$ promoted transition metal sulfides $\left(\mathrm{MoS}_{2}, \mathrm{WS}_{2}\right.$ or mixed Mo-W sulfides). ${ }^{12}$ This may modify bifunctional balance and catalyst performances. Indeed, transition metal sulfides (TMS) are known to have a much lower (de)hydrogenation activity than $\mathrm{Pt} .{ }^{13}$ Moreover, heavy oil fractions systematically contain nitrogen compounds, which act as inhibitors of the acid sites. ${ }^{14,15}$ One may, therefore, wonder to which extent transition metal sulfides affect the activity and selectivity of the bifunctional hydrocracking catalyst, in the presence or absence of inhibitors. ${ }^{16}$ In spite of the huge industrial importance of transition metal based hydrocracking catalysts these questions have not been addressed in detail in the existing literature.

A common methodology to evaluate the activity and selectivity and determine the optimum metal loading of hydrocracking catalysts is to use the hydroisomerization of n-hexadecane as a model reaction. ${ }^{6,17-26}$ In this work, this was done for a series of catalysts by using different loadings of either Pt or Ni-promoted transition metal sulfides as the hydrogenation function impregnated on acid supports containing variables contents of zeolite USY. In order to get closer to realistic industrial conditions, the pressure was set to 40 bar. The tests were carried out in the 
presence or absence of $\mathrm{NH}_{3}$, to evaluate the effect of this inhibitor representative of nitrogen compounds present in hydrocracking feedstocks on activity and selectivity of both types of catalysts as well as the deviation from "ideality", particularly for sulfide catalysts.

\section{Experimental section}

\section{Catalyst preparation}

Industrial hydrocracking catalysts are not used in the form of powders, but are shaped to extrudates by mixing the zeolite with a binder and impregnating the metallic function on the shaped zeolite. For the present study, boehmite was used as binder. It was mixed with the USY zeolite CBV720 (Zeolyst International) in different proportions to generate a paste that was kneaded and extruded. The extrudates had a diameter of $1.6 \mathrm{~mm}$ and were sorted to a length between 3 and $6 \mathrm{~mm} .4$ different zeolite contents were used in the extrudates : 3, 11.5, 17.5 and $50 \mathrm{wt} \%$. The advantage of varying the acidity of the extrudate via the zeolite content and not via the degree of dealumination of the zeolite is that the nature of the acid sites is not modified, only their concentration in the extrudate changes. The extrudates were calcined in wet air (6 vol\% $\left.\mathrm{H}_{2} \mathrm{O}\right)$ at $600^{\circ} \mathrm{C}$ for $2 \mathrm{~h}$.

Pt-USY- $\mathrm{Al}_{2} \mathrm{O}_{3}$ catalysts were prepared by incipient wetness impregnation of an aqueous solution of $\mathrm{Pt}\left(\mathrm{NH}_{3}\right)_{4} \mathrm{Cl}_{2}$ on the extrudate particles. The work of Zecevic et al. showed that this method should lead to a preferential deposition of Pt on the zeolite crystals (and not on the alumina support). ${ }^{7}$ A Zinsser robot was used for the impregnation. The Pt loading was varied between $0.1,0.6$ and $1 \mathrm{wt} \% \mathrm{Pt}$. The impregnated particles were dried at $120^{\circ} \mathrm{C}$ for $2 \mathrm{~h}$ and then

calcined in flowing air at $450^{\circ} \mathrm{C}$ for $1 \mathrm{~h}$. The dispersion of the Pt particles was not measured assuming that it should be similar for all the catalysts. ${ }^{27}$ The objective was only to reach a $\mathrm{Pt}$ level that provides a well-balanced catalyst. The test results showed that the highest activity and 
selectivity to $\mathrm{C}_{16}$ isomers was always reached at $1 \mathrm{wt} \% \mathrm{Pt}$ loading whatever the content of zeolite. Therefore, only these results will be presented in the following.

NiMo-USY- $\mathrm{Al}_{2} \mathrm{O}_{3}$ catalysts were prepared by incipient wetness of an aqueous solution containing Ni, P and Mo in molar proportions of $0.4 / 0.48 / 1 .^{28}$ The sources of Ni, $\mathrm{P}$ and Mo were $\mathrm{Ni}(\mathrm{OH})_{2}, \mathrm{H}_{3} \mathrm{PO}_{4}$ and $\mathrm{MoO}_{3}$, respectively. The $\mathrm{MoO}_{3}$ loading of the catalysts was varied between 12 and $24 \mathrm{wt} \%$, by adjusting the concentration of the impregnation solution. We note that it becomes challenging to reach much higher Mo loadings than $24 \mathrm{wt} \% \mathrm{MoO}_{3}$, because we approach the limit imposed by the product of pore volume of the support and solubility of the Mo species in the impregnation solution at room temperature. After impregnation, the catalysts were dried at $120^{\circ} \mathrm{C}$. Their Loss on Ignition (LOI) and their Tapped Bulk Density (TBD) were measured. Note that the $\mathrm{MoO}_{3}$ loading is expressed with respect to the catalyst mass taking into account its LOI. Table 1 lists all the sulfide-based catalysts which were prepared.

Table 1. USY and $\mathrm{MoO}_{3}$ contents (on dry basis) of the NiMo-USY- $\mathrm{Al}_{2} \mathrm{O}_{3}$ catalysts used in this study.

\begin{tabular}{cc}
\hline $\begin{array}{c}\text { USY loading in the support, } \\
\mathrm{wt} \%\end{array}$ & $\mathrm{MoO}_{3}$ content of catalyst, wt\% \\
\hline 3 & 24 \\
\hline 11.5 & $14,19,24$ \\
\hline 17.5 & $14,19,24$ \\
\hline 50 & 12 \\
\hline
\end{tabular}

\section{Catalyst testing}

\section{Pt Catalysts}

Pt-catalysts were tested on a Flowrence unit from Avantium, which allowed testing 16 catalysts in parallel. $0.32 \mathrm{~g}$ of each catalyst were loaded in each reactor of $2.6 \mathrm{~mm}$ of internal diameter. The free space between the extrudate particles was filled with Zirblast. After loading 
the catalysts in the reactors, they were reduced in flowing $\mathrm{H}_{2}$ at 40 bar and $450^{\circ} \mathrm{C}$ (for $1 \mathrm{~h}$ ). Then the temperature of the reactors was set to the first reaction temperature and the feed (pure $n-C_{16}$ ) was injected. The reaction was carried out at LHSV $=1.5 \mathrm{~h}^{-1}$ and 40 bar. The molar $\mathrm{H}_{2} / \mathrm{n}-\mathrm{C}_{16}$ ratio was equal to 10 . The temperature was varied from 180 to $350^{\circ} \mathrm{C}$. The reactor was operated as a trickle bed. Downstream of the pressure release value, the effluent was diluted and kept hot in order to avoid condensation and allow online sampling into a gas chromatograph. Several GC analyses were carried out for each reactor at each temperature, to ensure the stabilization of catalyst activity.

For experiments in the presence of $\mathrm{NH}_{3}, 0.7 \mathrm{wt} \%$ of n-octylamine was added to the feed. After decomposition of n-octylamine to n-octane and $\mathrm{NH}_{3}$, this corresponds to a concentration of 750 ppm $\mathrm{NH}_{3}$. In that case, the reaction temperature was gradually decreased from 415 to $255^{\circ} \mathrm{C}$ instead of being increased, in order to avoid the need for long stabilization periods due to slow desorption of $\mathrm{NH}_{3}$.

\section{NiMo Catalysts}

NiMo catalysts were tested in a fixed bed high pressure reactor. The reactor had an internal diameter of $10 \mathrm{~mm}$. It was filled with 2 to $4 \mathrm{~cm}^{3}$ of catalyst, diluted with $\mathrm{SiC}$ so as to reach a total volume of $8 \mathrm{~cm}^{3}$. Two pumps allowed to feed the reactor either with the mixture used for activation (sulfidation) or with the feed mixture for the catalytic test. The liquid flow rate was controlled by Quantim flow controllers. The liquid feed was mixed with $\mathrm{H}_{2}$ and then flowed through the reactor in downflow mode. At the reactor exit, the gas mixture was diluted with $\mathrm{N}_{2}$ to avoid condensation. A Kammer valve downstream of the reactor regulated the pressure in the unit. After releasing the pressure, the gas mixture was injected into an online GC via a Valco 6way valve. 
The catalyst was sulfided in situ with a mixture containing $20 \mathrm{wt} \%$ toluene, $73.5 \mathrm{wt} \%$ cyclohexane, $0.5 \mathrm{wt} \%$ aniline (for experiments in the presence of $\mathrm{NH}_{3}$ ) and $6 \mathrm{wt} \%$ dimethyldisulfide (DMDS). The $\mathrm{H}_{2} /$ hydrocarbon ratio was kept at $1000 \mathrm{NL} / \mathrm{L}\left(13 \mathrm{~mol} \mathrm{H} / \mathrm{mol} \mathrm{n}_{2} \mathrm{C}_{16}\right)$. The pressure was regulated at $40 \mathrm{bar}$, the LHSV was set to $2 \mathrm{~h}^{-1}$. The reactor was heated to $400^{\circ} \mathrm{C}$ with a ramp of $2^{\circ} \mathrm{C} / \mathrm{h}$ and kept at this temperature for $2 \mathrm{~h}$.

After completing the sulfidation the temperature was adjusted to the first reaction temperature and the feed was switched to the reaction mixture, which was composed of $98 \mathrm{wt} \% \mathrm{n}-\mathrm{C}_{16}, 1.5$ wt\% DMDS and $0.5 \mathrm{wt} \%$ aniline (corresponding to $750 \mathrm{ppm} \mathrm{NH}_{3}$ after decomposition). In the experiments in the absence of $\mathrm{NH}_{3}$, aniline was replaced by $\mathrm{n}-\mathrm{C}_{16}$ and the sulfidation temperature was reduced to $350^{\circ} \mathrm{C}$.

In a standard experiment, the LHSV was varied at each temperature, going from low to high LHSV. At each LHSV, at least 4 GC injections were carried out to make sure that the catalyst activity had stabilized before changing the operating conditions. Then the temperature was changed and the procedure was repeated. As in catalytic tests with Pt-catalysts, for experiments in the presence of $\mathrm{NH}_{3}$, the temperature was varied from high to low values in order to ensure a quick stabilization of the catalyst. Increasing temperature would lead to a sluggish desorption of $\mathrm{NH}_{3}$ and provoke long stabilization times.

\section{Calculations}

The GC analysis of the reactor effluent allows identifying all reaction products. Iso- $\mathrm{C}_{16}$ molecules are classified in mono- and dibranched products. Likewise, cracking products were classified in linear and branched paraffins (n- and i-paraffins). The peak areas were converted into mass fractions using response factors from the literature. ${ }^{29}$ The conversion was calculated as follows. 
$X=1-\frac{\% m_{n C 16}}{\sum_{i} \% m_{i}} \quad$ Equation 1

$\mathrm{m}_{\mathrm{i}}$ is the mass fraction of product $\mathrm{i}$ in the effluent.

For the Pt catalysts (tests in presence of $\mathrm{NH}_{3}$ ), the formation of octane from octylamine was not corrected for, since the impact on conversion and selectivity was negligible.

For the experiments with sulfide catalysts, $\mathrm{CH}_{4}$ was excluded from the calculation of the sum since it is produced by the decomposition of DMDS (i.e. we decided to ignore a possible formation of $\mathrm{CH}_{4}$ from $n-\mathrm{C}_{16}$ by hydrogenolysis). In the experiments, where aniline was added to the feed, the decomposition of aniline must be paid attention to. Aniline decomposes into $\mathrm{NH}_{3}$ and benzene, which can be further hydrogenated to cyclohexane. For the experiments with sulfide catalysts, we decided to ignore the formation of benzene (i.e. exclude benzene from the sum), but not the formation of cyclohexane, since sulfide catalysts have some cyclisation activity (meaning that cyclohexane could also be formed from $\mathrm{n}-\mathrm{C}_{16}$ ). The impact of this choice on the calculated activities and selectivities was negligible.

The yield of isomer products was calculated as follows :

$$
Y_{i C 16}=\frac{\% m_{i C 16}}{\sum \% m_{i}} \quad \text { Equation } 2
$$

The yield of cracking products was calculated as the sum over the mass fractions of all products with a carbon number lower than 16 (with the exceptions mentioned in the previous paragraph). It corresponds to the difference between conversion and i- $\mathrm{C}_{16}$ yield.

$$
\mathrm{Y}_{\text {cracking }}=\mathrm{X}-\mathrm{Y}_{\mathrm{i}-\mathrm{Cl} 16} \quad \text { Equation } 3
$$

Assuming first order kinetics, the rate constants were calculated using the following equation 
$k=L H S V \cdot \ln \frac{1}{1-X} \quad$ Equation 4,

where LHSV is the volumetric feed flow rate (using the density at $15^{\circ} \mathrm{C}$ ) divided by the volume of the catalyst bed (mass of catalyst divided by the Tapped Bulk Density).

\section{Results}

\section{Acidity of the catalysts}

The USY zeolite used in this work is a commercial sample (CBV720), whose characterization has been widely reported in the literature. ${ }^{30-32}$ The batch that we used has a framework $\mathrm{Al}$ concentration, i.e. the $\mathrm{Al}$ content from chemical analysis multiplied by the fraction of $\mathrm{Al}^{\mathrm{IV}}$ atoms in the ${ }^{27} \mathrm{Al} \mathrm{NMR}$ spectrum, of $820 \mu \mathrm{mol} / \mathrm{g} .{ }^{28}$ Denayer et al. showed that the acid site concentration determined by this method fitted well with the results of $\mathrm{NH}_{3}$ TPD as well as with measurements of the ion exchange capacity. ${ }^{30}$ The turnover frequency of USY zeolites was reported to depend on the concentration of extraframework species, ${ }^{31}$ which may modify acid strength. ${ }^{33,34}$ In our approach, we do not modify the acidity of the catalyst by varying the degree of dealumination, but we vary the USY content in the extrudate. This allows a scalar tuning of the number of acid sites, without modifying their nature. It was recently confirmed that the concentration of acid sites in an extrudate particle is indeed proportional to its zeolite content. ${ }^{35}$

\section{Pt catalysts}

Hydroisomerization in the absence of $\mathrm{NH}_{3}$ 


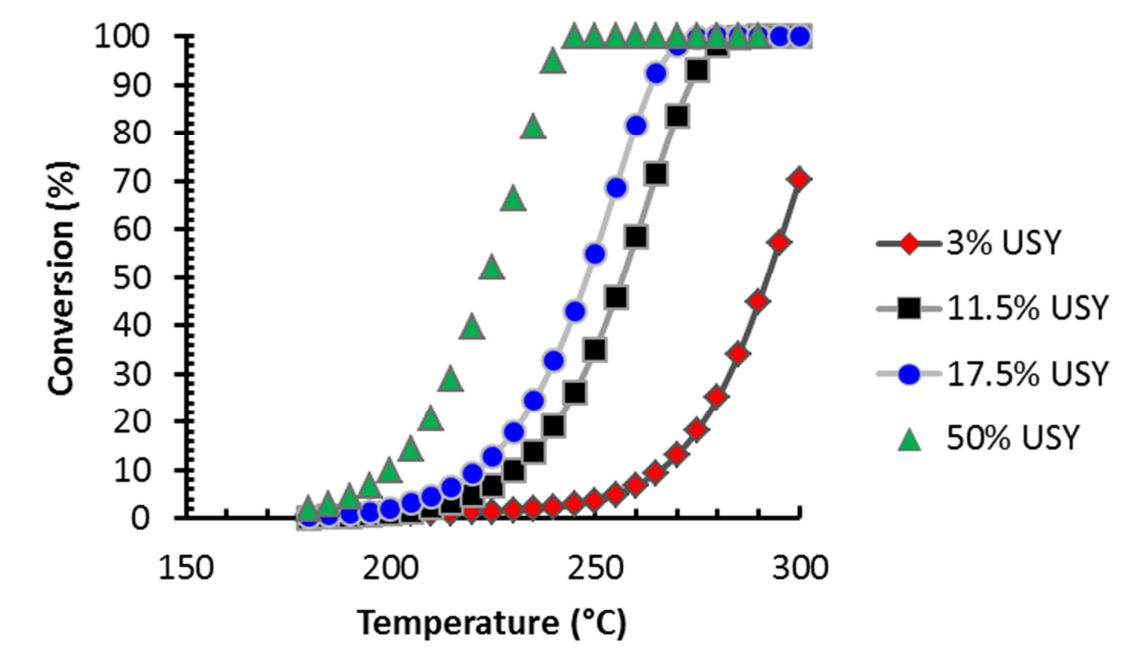

a)

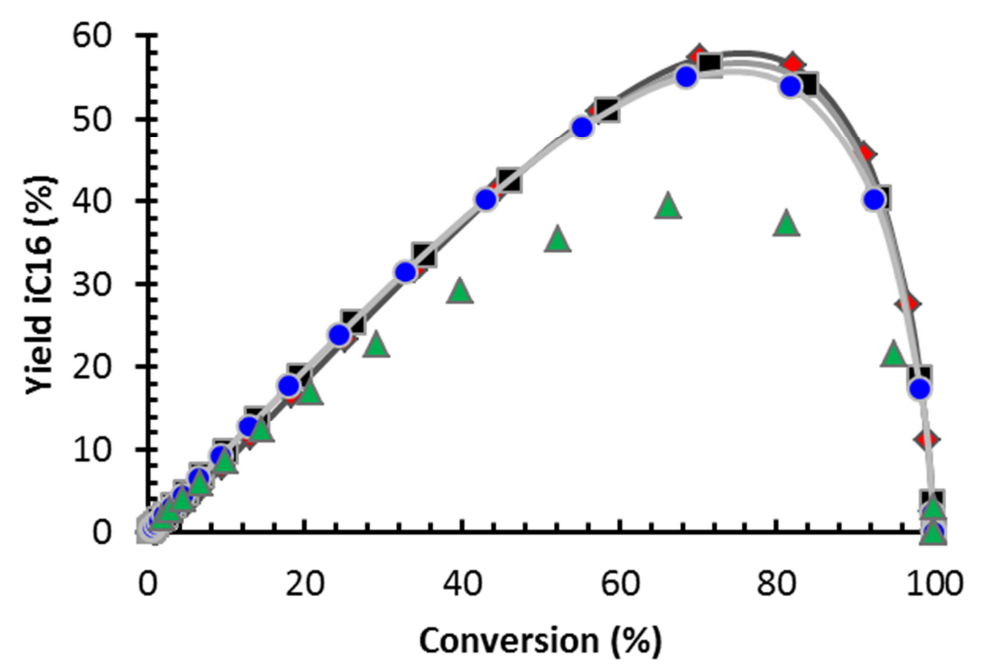

b)

Figure 1. a) Conversion of $\mathrm{n}-\mathrm{C}_{16}$ over $1 \mathrm{wt} \%$ Pt-USY- $\mathrm{Al}_{2} \mathrm{O}_{3}$ catalysts with different USY loadings. b) Yield of $\mathrm{i}-\mathrm{C}_{16}$ isomers as a function of conversion.

Figure 1a shows the $\mathrm{n}-\mathrm{C}_{16}$ conversion over Pt-catalysts as a function of temperature. The conversion obviously increased with USY loading. We choose an intermediate temperature, i.e. $220^{\circ} \mathrm{C}$, in order to compare the first order rate constants of the four catalysts (Table 2). Unexpectedly, the rate constants were not fully proportional to the zeolite loading. $\mathrm{k}$ increased faster than the loading, especially for the catalyst with $50 \%$ zeolite loading. It is possible that the latter result is due to the fact that the $50 \mathrm{wt} \%$ zeolite catalyst was far from being balanced and 
favored cracking reactions (Figure 1b), i.e. we are not looking at the same reactions when calculating the apparent activity.

We further note that the activation energy of the catalysts had a tendency to decrease with increasing zeolite loading in the support (Table 2). This trend may be related to the metal-acid balance of the catalysts. Thybaut et al. explained that the activation energy is expected to decrease if one moves from an ideal to a non-ideal (ill-balanced) catalyst. ${ }^{36}$

Table 2. First order rate constants of $n-\mathrm{C}_{16}$ conversion in absence of $\mathrm{NH}_{3}$, over $\mathrm{Pt}_{-} \mathrm{Al}_{2} \mathrm{O}_{3}-\mathrm{USY}$ catalysts at $220^{\circ} \mathrm{C}$, temperature required to reach $50 \%$ conversion, activation energy and maximum yield of $\mathrm{i}-\mathrm{C}_{16}$

\begin{tabular}{ccccc}
\hline $\begin{array}{c}\text { USY loading } \\
\mathrm{wt} \%\end{array}$ & $\begin{array}{c}\mathrm{k} 220^{\circ} \mathrm{C} \\
\mathrm{h}^{-1}\end{array}$ & $\begin{array}{c}\mathrm{T}_{50} \\
{ }^{\circ} \mathrm{C}\end{array}$ & $\begin{array}{c}\mathrm{E}_{\mathrm{a}} \\
\mathrm{kJ} / \mathrm{mole}\end{array}$ & $\begin{array}{c}\text { maximum } \\
\text { Yield i- } \mathrm{C}_{16} \%\end{array}$ \\
\hline 3 & 0.017 & 292 & 158 & 58 \\
\hline 11.5 & 0.075 & 257 & 152 & 57 \\
\hline 17.5 & 0.143 & 248 & 153 & 56 \\
\hline 50 & 0.94 & 221 & 144 & 39 \\
\hline
\end{tabular}

Figure $1 \mathrm{~b}$ shows the yield of $\mathrm{i}-\mathrm{C}_{16}$ isomers as a function of conversion. Except for the $50 \mathrm{wt} \%$ zeolite loading, the yield curves were similar; they represent the inherent yield pattern of USY CBV720 (at our operating conditions). Only for the $50 \mathrm{wt} \%$ USY catalyst a lower isomer yield was obtained, i.e. more cracking took place. For this catalyst, the metal function was not sufficient to hydrogenate the isomerized intermediates on the acid sites before they underwent cracking, meaning this catalyst was not well balanced.

\section{Hydroisomerization in the presence of $\mathrm{NH}_{3}$}

Figure 2a shows the conversion of $\mathrm{n}-\mathrm{C}_{16}$ in the presence of $750 \mathrm{ppm} \mathrm{NH} \cdot \mathrm{NH}_{3}$ is a very strong inhibitor of the acid sites. Hence, the temperatures necessary to achieve $50 \%$ conversion 
increased by 80 to $115^{\circ} \mathrm{C}$ depending on the catalyst, compared to the tests without $\mathrm{NH}_{3}$ (Table 3).

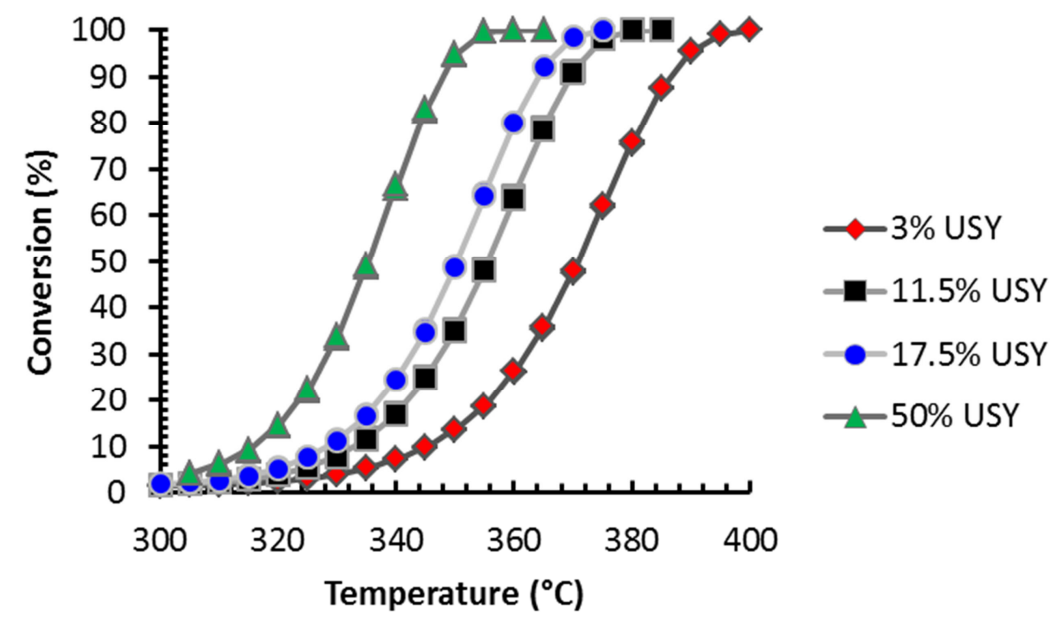

a)

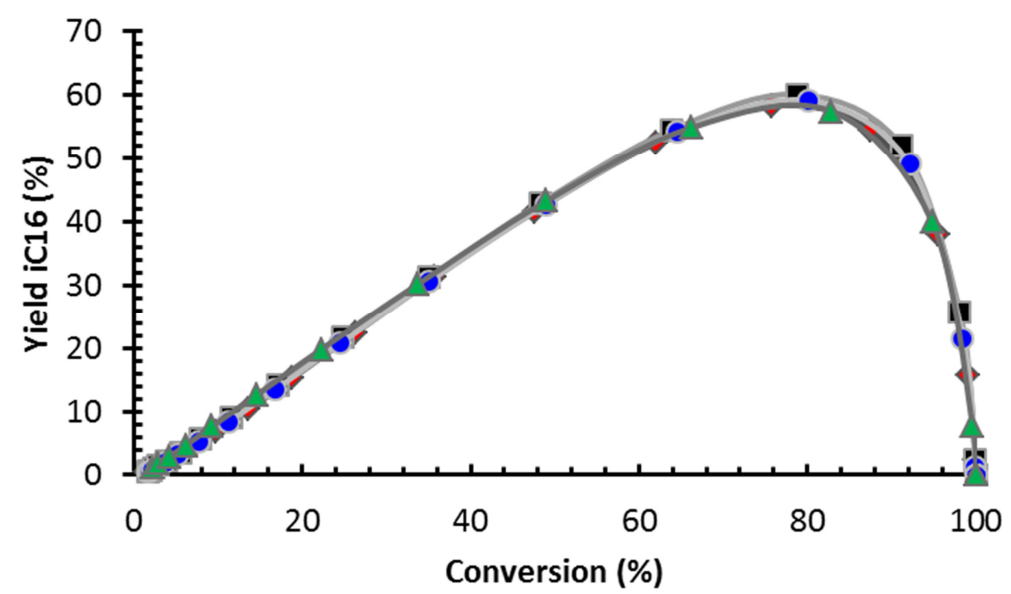

b)

Figure 2. a) Conversion of $n-\mathrm{C}_{16}$ in the presence of $750 \mathrm{ppm} \mathrm{NH}$ over $1 \mathrm{wt} \%$ Pt-USY- $\mathrm{Al}_{2} \mathrm{O}_{3}$ catalysts with different USY loadings. b) Yield of $\mathrm{i}-\mathrm{C}_{16}$ isomers as a function of conversion.

The $\mathrm{i}-\mathrm{C}_{16}$ yield vs. conversion curves of all the catalysts were identical, the maximum i- $\mathrm{C}_{16}$ yield in all cases was close to $60 \%$ (Figure 2b), which corresponds to the intrinsic yield of USY CBV720 ${ }^{37}$. In the presence of $\mathrm{NH}_{3}$, even the $50 \mathrm{wt} \%$ USY catalyst was balanced. This result seems trivial, since $\mathrm{NH}_{3}$ inhibits acid sites and, therefore, shifts the metal-acid balance in favor of the metal. However, in order to compensate the inhibition, the catalyst operates at higher 
temperatures. Isomerization/cracking reactions have a higher activation energy than (de)hydrogenation reaction, i.e. increasing the temperature will deteriorate the metal-acid balance. The trade-off between these two effects will be addressed in detail in the discussion.

The activation energy of the reaction also increased drastically, due to the energy necessary for the desorption of $\mathrm{NH}_{3}$. The activation energy increased with increasing zeolite loading.

We calculated the first order rate constants at $330^{\circ} \mathrm{C}$ (Table 3). In contrast to the tests without $\mathrm{NH}_{3}$, a fairly good linear relationship was obtained between the rate constants and the zeolite loading of the catalysts (in other words, a constant activity per mass of zeolite, as expected for balanced catalysts).

Table 3. First order rate constants of $n-\mathrm{C}_{16}$ conversion in presence of $\mathrm{NH}_{3}$, over Pt-USY- $\mathrm{Al}_{2} \mathrm{O}_{3}$ catalysts at $330^{\circ} \mathrm{C}$, temperature required to reach $50 \%$ conversion, activation energy and maximum yield of $\mathrm{i}-\mathrm{C}_{16}$

\begin{tabular}{ccccc}
\hline $\begin{array}{c}\text { USY loading } \\
\mathrm{wt} \%\end{array}$ & $\mathrm{k} 330^{\circ} \mathrm{C}$ & $\mathrm{T}_{50}$ & $\mathrm{E}_{\mathrm{a}}$ & $\begin{array}{c}\text { maximum Yield i- } \\
\mathrm{C}_{16} \\
\mathrm{~h}^{-1}\end{array}$ \\
\hline 3 & 0.03 & 372 & 232 & 58 \\
\hline 11.5 & 0.12 & 355 & 244 & 60 \\
\hline 17.5 & 0.18 & 350 & 251 & 59 \\
\hline 50 & 0.62 & 335 & 286 & 57 \\
\hline
\end{tabular}

\section{NiMo catalysts}

\section{Hydroisomerization in the presence of $\mathrm{NH}_{3}$}

We start by describing the results obtained in presence of $\mathrm{NH}_{3}$ as inhibitor of the acid sites, because we will see that the presence of the inhibitor allows us to balance the sulfide catalyst fairly well. Remember that the testing procedure was different from the Pt catalysts: the conversion was not varied by varying the temperature, but by modifying the space velocity at 
constant temperature $\left(360^{\circ} \mathrm{C}\right)$. In some cases, additional data points were measured at different temperatures in order to be able to evaluate activation energies. The rate constant $\mathrm{k}$ was obtained from average $\mathrm{LHSV} * \ln (1 /(1-\mathrm{X}))$ values at $360^{\circ} \mathrm{C}$ where moderate conversions were obtained.

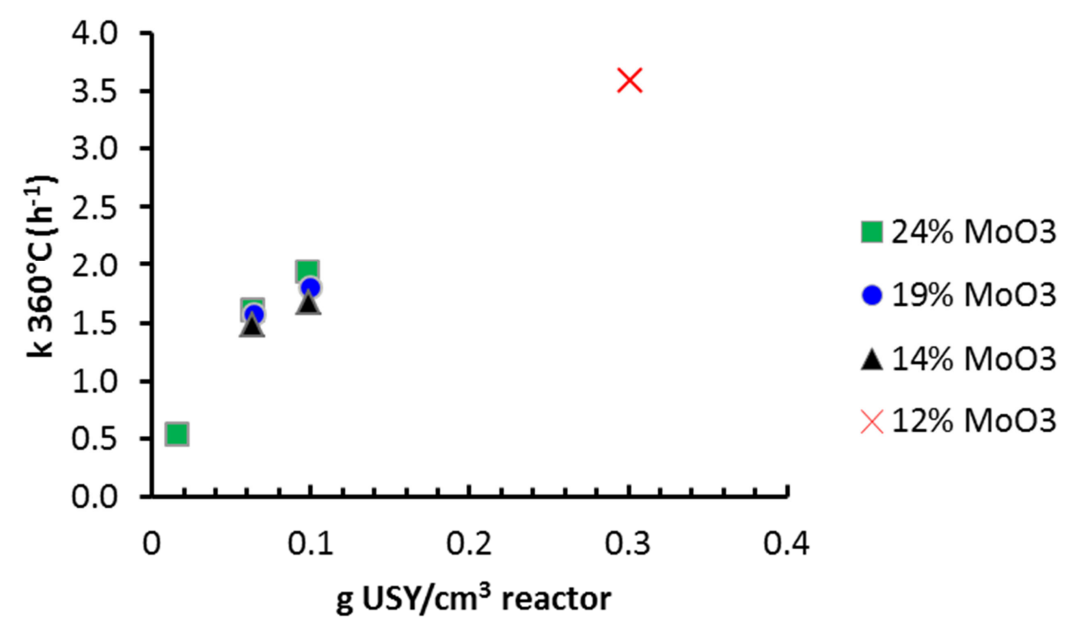

Figure 3. First order rate constant of hydroconversion of $n-\mathrm{C}_{16}$ over NiMo-USY- $\mathrm{Al}_{2} \mathrm{O}_{3}$ catalysts in the presence of $750 \mathrm{ppm} \mathrm{NH}_{3}$ as a function of the USY content in the reactor.

Figure 3 illustrates that the rate constant for the catalysts with different zeolite loadings depended mainly on the zeolite content in the reactor. The $\mathrm{MoO}_{3}$ content of the catalysts played a secondary role. Yet, increasing the $\mathrm{MoO}_{3}$ loading systematically led to a small increase in activity. 


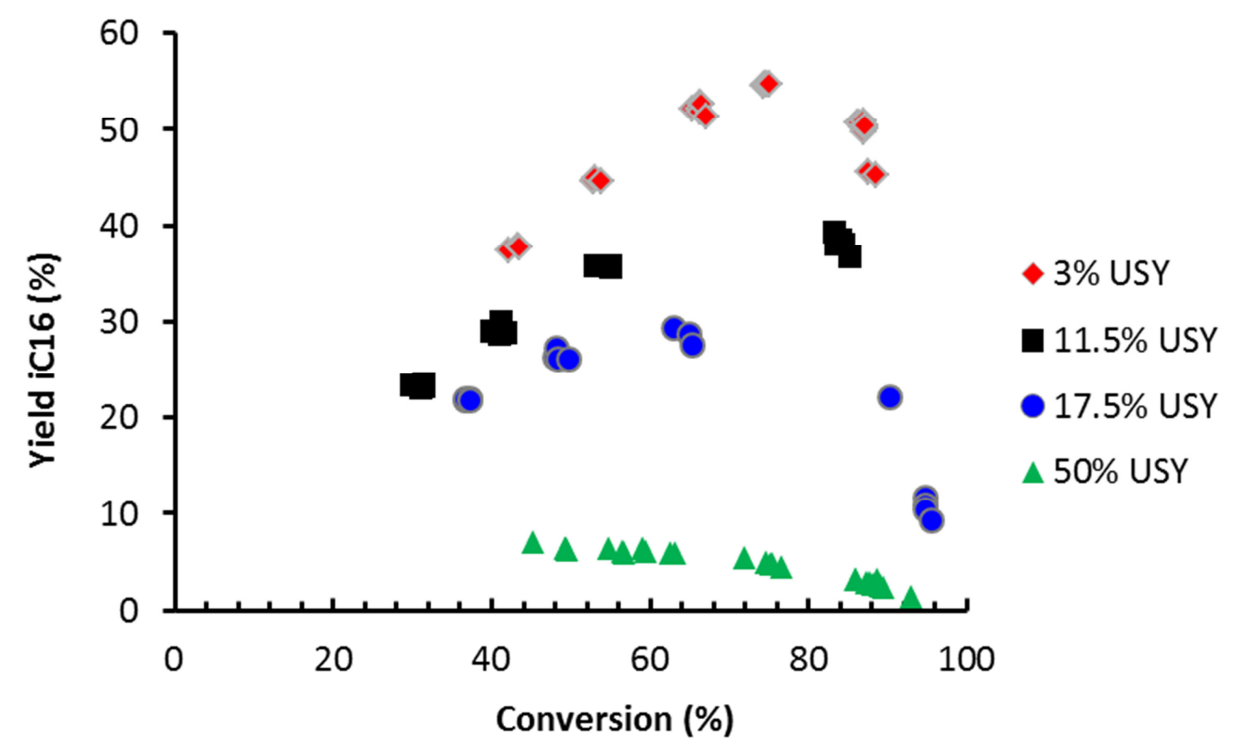

Figure 4. $\mathrm{i}-\mathrm{C}_{16}$ yield as a function of conversion at $360^{\circ} \mathrm{C}$ over NiMo-USY- $\mathrm{Al}_{2} \mathrm{O}_{3}$ catalysts in the presence of $750 \mathrm{ppm} \mathrm{NH}$. For each zeolite loading, the catalyst with the highest available $\mathrm{MoO}_{3}$ content was represented.

Figure 4 shows the $\mathrm{i}-\mathrm{C}_{16}$ yield as a function of conversion for the different catalysts. The zeolite content had a huge impact on the isomer yield: the highest yield was obtained with a low zeolite loading and vice versa. Note that the highest isomer yield was obtained for catalyst containing $3 \mathrm{wt} \%$ USY and $24 \mathrm{wt} \% \mathrm{MoO}_{3}$. It was equal to 54\%, i.e. slightly lower than the best yields obtained with the Pt catalysts (which were between 58 and 60\%). The other NiMo catalysts reached much lower isomer yields, i.e. they were insufficiently balanced. 


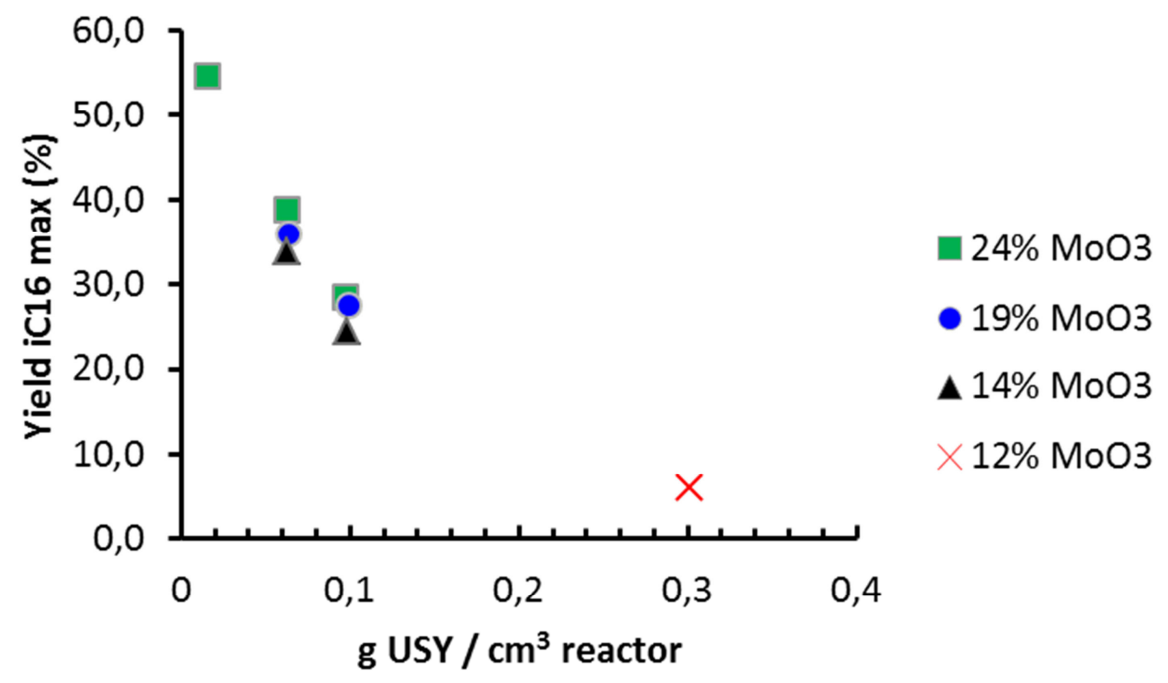

Figure 5. Maximum isomer yield versus zeolite content: NiMo-USY- $\mathrm{Al}_{2} \mathrm{O}_{3}$ catalysts in the presence of $750 \mathrm{ppm} \mathrm{NH}_{3}$

One can observe a negative correlation between catalyst selectivity and zeolite loading (Figure

5). The most active catalysts were least selective for isomers. For catalysts with similar activity, i.e. the same zeolite loading, higher $\mathrm{MoO}_{3}$ loading led to slightly higher isomer yields. Although the $\mathrm{MoO}_{3}$ loading was varied over a large range, its impact on activity and selectivity was quite small. Both were mainly governed by the zeolite loading of the catalysts, the $\mathrm{MoO}_{3}$ content only allowed slight adjustments.

\section{Hydroisomerization in the absence of $\mathrm{NH}_{3}$}

When the hydroisomerization was carried out in the absence of $\mathrm{NH}_{3}$ as inhibitor, the catalyst activity drastically increased. To achieve similar conversions as in the presence of $\mathrm{NH}_{3}$, the reactor temperature had to be about $75^{\circ} \mathrm{C}$ lower. The activation energy of the reaction also strongly decreased to $145 \mathrm{~kJ} / \mathrm{mol}$, reaching values very similar to those obtained for Pt catalysts. 


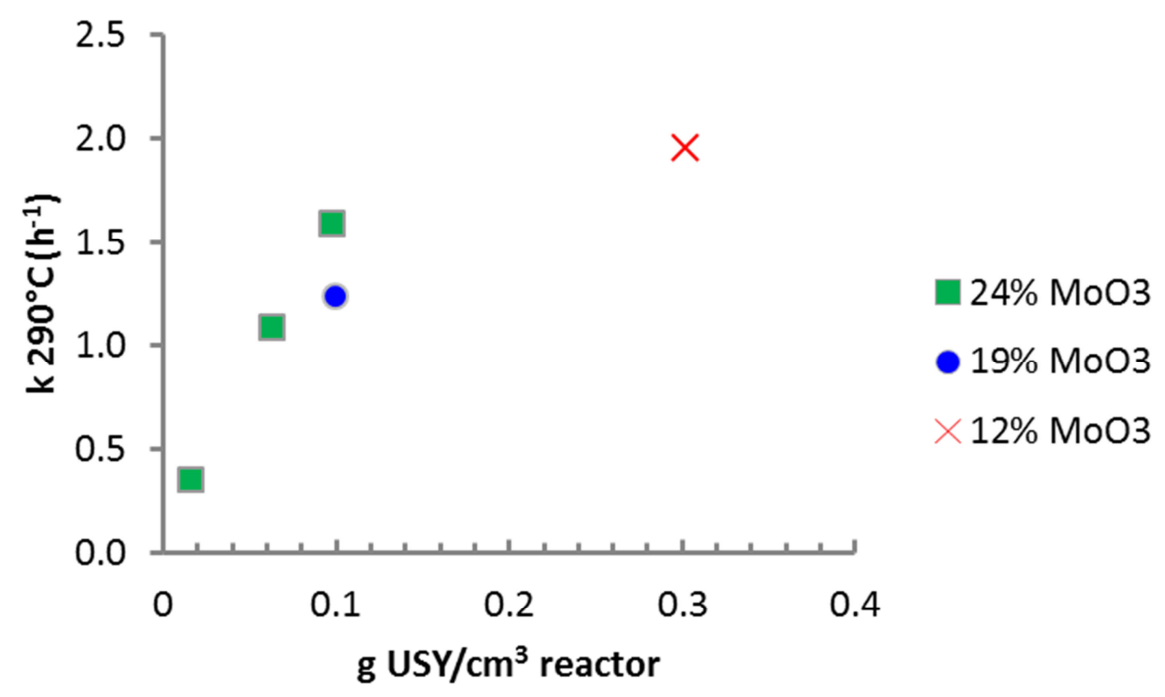

Figure 6. First order rate constant of hydroconversion of $n-\mathrm{C}_{16}$ over NiMo- $\mathrm{Al}_{2} \mathrm{O}_{3}-\mathrm{USY}$ catalysts at $290^{\circ} \mathrm{C}$ as a function of the USY content in the reactor.

Figure 6 shows the first order rate constants at $290^{\circ} \mathrm{C}$ as a function of USY content in the reactor. Up to $17.5 \mathrm{wt} \%$ USY $\left(0.1 \mathrm{~g} \mathrm{USY} / \mathrm{cm}^{3}\right)$, a fairly linear relationship between $\mathrm{k}$ and the USY content is observed, i.e. the activity is governed by the acidity. The effect of the $\mathrm{MoO}_{3}$ loading was, however, more pronounced than in the tests with $\mathrm{NH}_{3}$; the difference between 19 wt $\% \mathrm{MoO}_{3}$ and 24 wt $\% \mathrm{MoO}_{3}$ was clearly visible in the absence of $\mathrm{NH}_{3}$ (compare with Figure 3). The catalyst with $50 \mathrm{wt} \%$ USY loading $\left(0.3 \mathrm{~g} \mathrm{USY} / \mathrm{cm}^{3}\right)$ was only $30 \%$ to $50 \%$ more active than the ones with $17.5 \mathrm{wt} \%$ USY, probably because the metal function (only $12 \mathrm{wt} \% \mathrm{MoO}_{3}$ ) was too weak to supply the acid sites. 


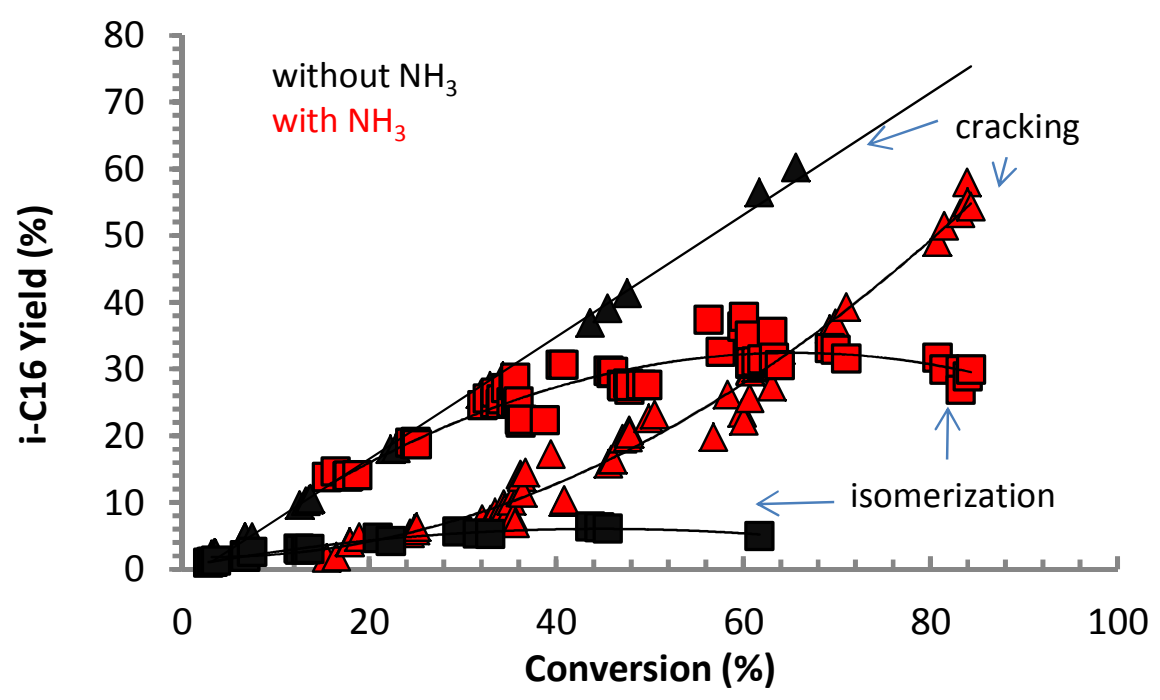

Figure 7.Yield of cracking products (triangles) and $\mathrm{i}-\mathrm{C}_{16}$ (squares) as a function of conversion. Black symbols: reaction in absence of $\mathrm{NH}_{3}$, red symbols: reaction in presence of $\mathrm{NH}_{3}$. Catalyst NiMo-USY- $\mathrm{Al}_{2} \mathrm{O}_{3}$ (17.5 wt $\%$ USY, $19 \mathrm{wt} \% \mathrm{MoO}_{3}$ )

As illustrated by Figure 7, the main reaction pathway radically changed in the absence of $\mathrm{NH}_{3}$. Cracking products became the main reaction products already at very low conversion levels, meaning that the NiMo sulfide was unable to hydrogenate the olefins formed and avoid cracking of the reaction intermediates on the acid sites.

\section{Discussion}

\section{Inhibition of acid sites by $\mathrm{NH}_{3}$}

$\mathrm{NH}_{3}$ is a very strong inhibitor of the acid sites. In the presence of $\mathrm{NH}_{3}$, it was necessary to increase the reaction temperature by more than $80^{\circ} \mathrm{C}$ to achieve similar conversions than in the absence of $\mathrm{NH}_{3}$ for Pt or Sulfide-based catalysts The activation energy increased strongly, as observed in earlier studies ${ }^{28,38}$. Interestingly, the increase of the activation energy depended on the zeolite loading (Figure 8), it increased from 80 to $140 \mathrm{~kJ} / \mathrm{mol}$ depending on the catalysts. 


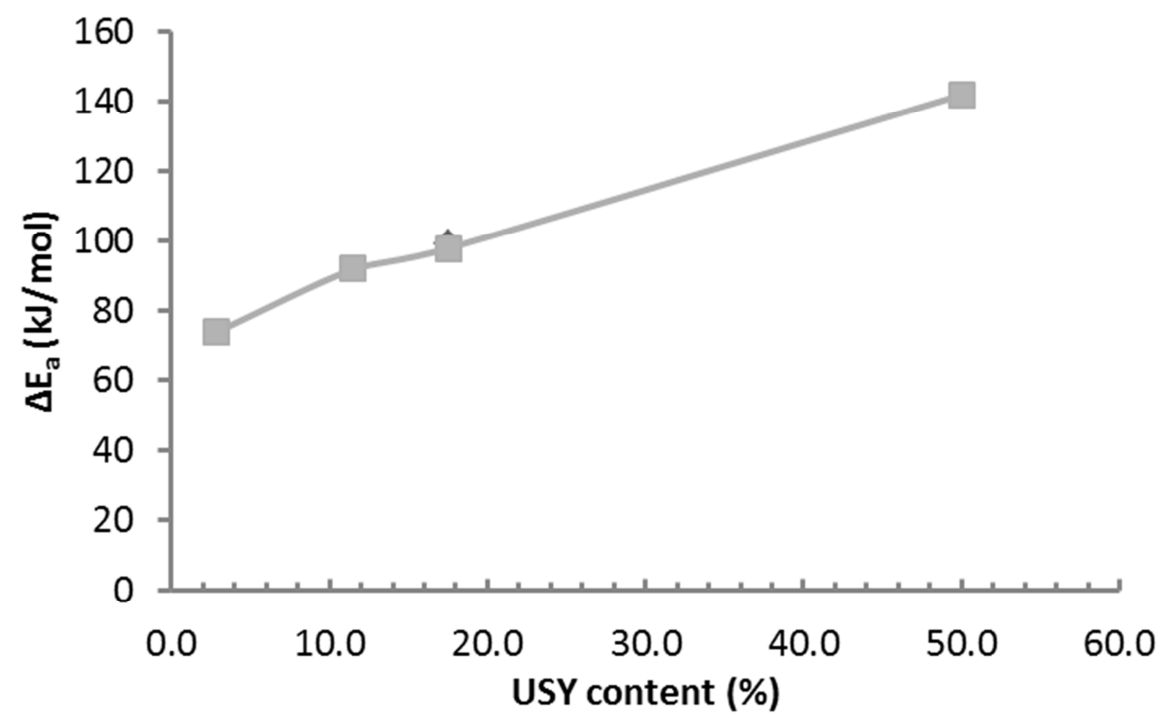

Figure 8. Difference in the activation energy of Pt-USY- $\mathrm{Al}_{2} \mathrm{O}_{3}$ catalysts in the presence and absence of $\mathrm{NH}_{3}$

If we assume that $\mathrm{NH}_{3}$ is the dominating inhibitor (i.e. its adsorption is much stronger than that of $\mathrm{n}-\mathrm{C}_{16}$ and the fraction of vacant sites is low), the effective rate constant $\mathrm{k}$ can be expressed as:

$$
\mathrm{k}=\mathrm{k}_{\mathrm{a}} * \mathrm{n}_{\mathrm{acid}} *\left(1-\Theta_{\mathrm{NH} 3}\right)=\mathrm{k}_{\mathrm{a}} * \mathrm{n}_{\mathrm{acid}} /\left(\mathrm{K}_{\mathrm{NH} 3} * \mathrm{p}_{\mathrm{NH} 3}\right) \quad \text { Equation } 5
$$

According to this formalism the increase of the activation energy due to the presence of $\mathrm{NH}_{3}$ should correspond to $-\Delta \mathrm{H}_{\mathrm{NH} 3} \cdot{ }^{39}$ The adsorption enthalpy of ammonia on USY zeolites $\left(\Delta \mathrm{H}_{\mathrm{NH} 3}\right)$ was reported to be between -120 and $-180 \mathrm{~kJ} / \mathrm{mol}^{40-42}$ The $\Delta \mathrm{E}_{\mathrm{a}}$ values which we found (Figure 8) were shifted to a lower range, especially for the low zeolite contents. A tentative explanation for the low $\Delta \mathrm{E}_{\mathrm{a}}$ of the $3 \mathrm{wt} \% \mathrm{USY}$ catalyst is that this catalyst operated in a higher temperature range, i.e. in a regime where the hypothesis of a high coverage of acid sites by $\mathrm{NH}_{3}$ does not hold anymore. This would temper the effect of $\mathrm{NH}_{3}$ on the activation energy.

It is interesting to estimate the fraction of acid sites that remains vacant in the presence of $\mathrm{NH}_{3}$. This exercise was recently carried out by Mendes et al. ${ }^{28}$ They compared the performances of NiMo-USY- $\mathrm{Al}_{2} \mathrm{O}_{3}$ catalysts in the isomerization of cyclohexane in the presence and absence of $\mathrm{NH}_{3}$. By calculating the ratio of the two rate constants, the study came to the conclusion that less 
than $1 \%$ of the acid sites was operating in the presence of $\mathrm{NH}_{3}$. For sulfide catalysts it is, however, delicate to relate the ratio of rate constants directly to the ratio of available acid sites, since the effective rate constants are potentially influenced by the dehydrogenation function, which is not necessarily sufficient to aliment all the acid sites. For well-balanced Pt-catalysts we can assume that their catalytic activity is exclusively governed by the acid function. Hence, the calculation of the ratio of rate constants in the presence and absence of $\mathrm{NH}_{3}$ should allow a precise evaluation of the fraction of vacant acid sites.

Since the temperature ranges of the activity data with and without $\mathrm{NH}_{3}$ barely overlap (see Figure 1 and 2), an Arrhenius equation was used to extrapolate the rate constants at a common temperature range. The results of the exercise are shown in Figure 9. We can see that the activity ratio of the two catalysts with intermediate zeolite loadings (11.5 and 17.5 wt\% USY) are identical. This result is expected since we are dealing with the same zeolite. The catalyst with low zeolite loading ( $3 \mathrm{wt} \%$ USY) had a somewhat higher activity ratio, which may again find an explanation in the temperature regime (at the high temperatures used for testing the $3 \mathrm{wt} \%$ USY catalyst the hypothesis of low fraction of vacant sites in the presence of $\mathrm{NH}_{3}$ is not fully valid).

Figure 9 illustrates that for a partial pressure of $\sim 0.05$ bar $\mathrm{NH}_{3}$, less than $1 \%$ of the acid sites was vacant at $350^{\circ} \mathrm{C}$. At $250^{\circ} \mathrm{C}$, the fraction of vacant sites was in the order of $10^{-4}$. Only a tiny fraction of the acid sites was operating in the presence of $\mathrm{NH}_{3}$. 


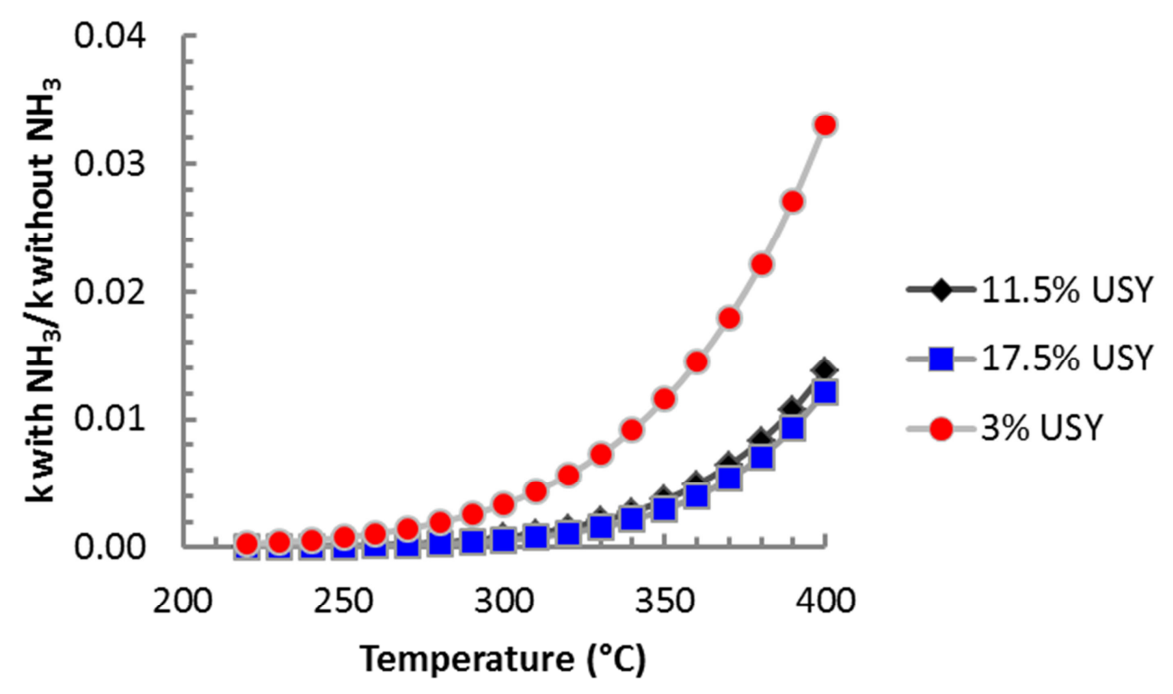

Figure 9. Ratio of rate constants of balanced Pt-USY- $\mathrm{Al}_{2} \mathrm{O}_{3}$ catalysts (extrapolated from an Arrhenius equation) in the presence and absence of $\mathrm{NH}_{3}$.

\section{Metal-acid balance of Pt catalysts}

With the exception of the $50 \mathrm{wt} \%$ USY support, all Pt catalysts followed the same $\mathrm{i}-\mathrm{C}_{16}$ yield vs. conversion curve, with a maximum isomer yield of $~ 58 \%$ (Figure S1). This yield corresponds to the intrinsic selectivity of USY CBV720 under our reaction conditions. The only ill balanced catalyst (50 wt\%USY) became balanced when the hydroisomerization reaction was carried out in the presence of $\mathrm{NH}_{3}$. As mentioned in the results section, this result is not trivial and merits a profound examination.

In order to quantify the metal-acid balance we rely on the methodology of Degnan and Kennedy. ${ }^{43}$ They developed a simplified kinetic model of hydroisomerisation, which is very well suited to analyze the deviation from "ideal" behavior. ${ }^{27}$ The model shows that the maximum yield of isomers $\mathrm{Y}_{\max }$ can be expressed by the simple equation

$$
Y_{\max }=v \cdot \lambda^{\lambda / 1-\lambda} \quad \text { Equation } 6
$$


The factor $\lambda$ is essentially the ratio between cracking and isomerization rate constants. It depends little on the ratio of acid to metal sites (see the article of Degnan and Kennedy for more details). We can consider $\lambda$ as being constant for all the samples in our study and also fairly independent of temperature since isomerization and cracking have similar activation energies. ${ }^{36}$

Differences in the maximum isomer yield are, therefore, attributed to the factor $v$, which is related to the kinetic constants of dehydrogenation and cracking as well as to the ratio of acid to metal sites:

$$
v=\frac{1}{1+\varepsilon \cdot \sigma} \quad \text { Equation } 7
$$

with $\varepsilon$ and $\sigma$ defined by equations 8 and 9 .

$$
\begin{array}{ll}
\varepsilon=\frac{k_{c}}{p_{H 2} \cdot k_{d e h}} & \text { Equation 8 } \\
\sigma=\frac{n_{\text {acid }} \cdot\left(1-\theta_{\text {acid }}\right)}{n_{\text {metal }} \cdot\left(1-\theta_{H}\right)^{2}} & \text { Equation 9 }
\end{array}
$$

$\mathrm{k}_{\mathrm{c}}$ and $\mathrm{k}_{\mathrm{deh}}$ are the rate constants of cracking and of dehydrogenation of iso-paraffins, respectively, $\left(1-\Theta_{\text {acid }}\right)$ is the fraction of vacant acid sites, $\Theta_{H}$ is the coverage of metal sites by hydrogen.

The equations show that $v$ and hence also the maximum isomer yield decrease when, (i) the rate constant of cracking increases relative to the rate constant of dehydrogenation, (ii) the ratio of acid to metal sites increases, (iii) the coverage of acid sites decreases.

We can now examine how $v$ evolves, when the reaction is carried out in the presence of $\mathrm{NH}_{3}$ and at much higher temperatures in order to compensate for the strong inhibition of the acid sites. Since we showed before that $\mathrm{NH}_{3}$ is very strongly adsorbed on the acid sites (in 
comparison the coverage by the reactant must be negligible ${ }^{39}$ ), we can express the coverage of acid sites as

$$
1-\theta_{\text {acid }}=\frac{1}{K_{N H 3} \cdot p_{N H 3}} \quad \text { Equation } 10
$$

We also have to take the coverage of metal sites into account. Theoretical calculations showed that the metal coverage by hydrogen at high pressure remains close to a full monolayer coverage up to temperatures of at least $400^{\circ} \mathrm{C}^{44,45}$ The fraction of free sites is, therefore, inversely proportional to the $\mathrm{H}_{2}$ partial pressure and the adsorption constant.

$$
\begin{array}{ll}
\left(1-\theta_{H}\right)^{2}=\frac{1}{K_{H 2} \cdot p_{H 2}} & \text { Equation } 11 \\
\varepsilon \cdot \sigma=\frac{k_{c, 0}}{k_{\text {deh }, 0}} \cdot \frac{n_{\text {acid }}}{n_{\text {metal }}} \cdot \frac{K_{0, H 2}}{K_{0, N H 3} \cdot p_{N H 3}} \cdot \exp \left(\frac{-\left(E_{c}-E_{d e h}-\Delta H_{N H 3}+\Delta H_{H 2}\right.}{R T}\right) \text { Equation } 12
\end{array}
$$

Equation 12 shows that the temperature dependence of $\varepsilon^{*} \sigma$, which is negatively correlated to the isomer yield, is related to an "activation energy" of $\mathrm{E}_{\mathrm{c}}-\mathrm{E}_{\mathrm{deh}}-\Delta \mathrm{H}_{\mathrm{NH} 3}+\Delta \mathrm{H}_{\mathrm{H} 2}$. $\mathrm{E}_{\mathrm{c}}$ is the activation energy of cracking, $\mathrm{E}_{\mathrm{deh}}$ the activation energy of dehydrogenation, $\Delta \mathrm{H}_{\mathrm{H} 2}$ the enthalpy of $\mathrm{H}_{2}$ adsorption on the metal sites.

On the other hand, the activity is proportional to $\mathrm{k}_{\text {isom }} *\left(1-\Theta_{\text {acid }}\right)$, which has an apparent activation energy of $\mathrm{E}_{\mathrm{isom}}-\Delta \mathrm{H}_{\mathrm{NH} 3}$. If the expression $\varepsilon^{*} \sigma$ evolves faster with temperature than the rate, then the metal-acid balance and hence the selectivity are negatively influenced by raising the temperature and vice versa. In other words, selectivity will increase if

$$
\begin{array}{lr}
\mathrm{E}_{\mathrm{c}}-\mathrm{E}_{\mathrm{deh}}-\Delta \mathrm{H}_{\mathrm{NH} 3}+\Delta \mathrm{H}_{\mathrm{H} 2}<\mathrm{E}_{\text {isom }}-\Delta \mathrm{H}_{\mathrm{NH} 3} & \text { Equation } 13 \\
\mathrm{E}_{\mathrm{c}}-\mathrm{E}_{\mathrm{isom}}-\mathrm{E}_{\mathrm{deh}}+\Delta \mathrm{H}_{\mathrm{H} 2}<0 & \text { Equation } 14
\end{array}
$$

Thybaut et al. demonstrated that $E_{\mathrm{c}} \sim \mathrm{E}_{\mathrm{isom}}{ }^{36}, \mathrm{E}_{\mathrm{deh}}$ is necessarily positive ${ }^{46}$ and the heat of adsorption of $\mathrm{H}_{2}$ on $\mathrm{Pt}$ is necessarily negative ${ }^{47}$. Hence, the condition is always fulfilled. The 
model, thus, predicts that the inhibition of acid sites by $\mathrm{NH}_{3}$ will improve the balance between metal and acid sites, even if the inhibition is compensated by an increase of the reaction temperature. A more rigorous demonstration is provided in the supporting information.

We note that we cannot fully exclude another, more trivial explanation for the beneficial effects of $\mathrm{NH}_{3}$ on selectivity. $\mathrm{NH}_{3}$ will preferentially inhibit the "strongest" acid sites, which are most prone to cracking. Yet, the concept of having acid sites of varying strength in a given zeolite lattice is contested, ${ }^{48}$ especially for zeolites which contain few extraframework species. Our demonstration above shows that the beneficial effect of $\mathrm{NH}_{3}$ will be necessarily found even for zeolites, which have perfectly uniform acid strength.

\section{Metal-acid balance of sulfide catalysts}

As mentioned in the introduction, we expect sulfide catalysts to be less well-balanced than $\mathrm{Pt}$ catalysts, because of the weaker (de)hydrogenation activity of the former. The present data allow us to quantify this effect more precisely (see also the parallel work of Mendes et al. ${ }^{49}$ ).

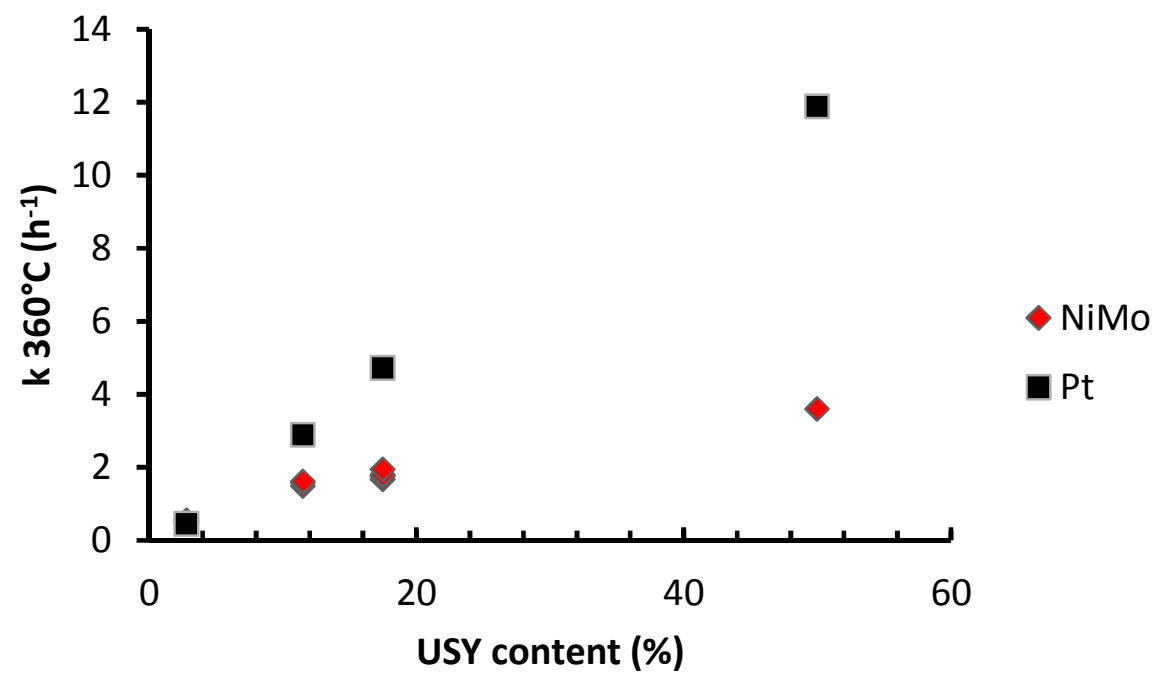

a) 


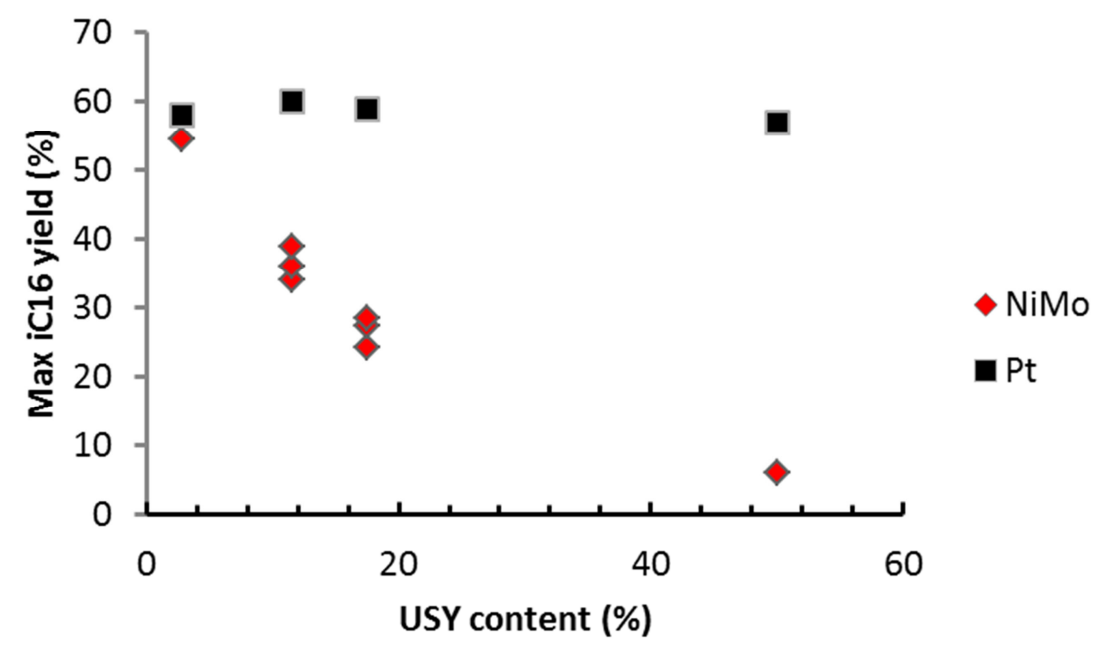

b)

Figure 10. a) Rate constant of Pt- and NiMo-USY- $\mathrm{Al}_{2} \mathrm{O}_{3}$ catalysts at $360^{\circ} \mathrm{C}$, in the presence of $\mathrm{NH}_{3}$; b) maximum i-C $\mathrm{C}_{16}$ yield as a function of USY content, in the presence of $\mathrm{NH}_{3}$.

Figure 10a compares the rate constants of $\mathrm{Pt}$ and NiMo catalysts at $360^{\circ} \mathrm{C}$ in the presence of $\mathrm{NH}_{3}$. For Pt-catalysts, the activity increased linearly with the zeolite loading, while the activity of NiMo catalysts increased much slower and seemed to converge towards a plateau value. Only for the lowest zeolite loading ( $3 \mathrm{wt} \%$ USY), the Pt and the NiMo catalyst had similar rate constants. For higher zeolite loadings, the NiMo function was not able to aliment all the acid sites of the support.

A similar trend was observed for the $\mathrm{i}-\mathrm{C}_{16}$ yield. Pt catalyst had a constant $\mathrm{i}-\mathrm{C}_{16}$ selectivity, independent of zeolite loading. For NiMo catalysts, the $\mathrm{i}-\mathrm{C}_{16}$ yield decreased with USY content and only the support with $3 \mathrm{wt} \%$ USY reached an isomer yield that was close to the Pt catalysts.

Figure 10 clearly demonstrates that NiMo catalysts can be balanced under two conditions: (i) $\mathrm{NH}_{3}$ must be present as an inhibitor of the acid sites. (ii) The zeolite loading must be low.

In the absence of $\mathrm{NH}_{3}$, however, it becomes impossible to balance the acid sites of USY with a NiMo function, the catalysts become completely unselective for isomerization, cracking becomes the main reaction (Figure 7). Concerning activity, the rate constant $\mathrm{k}$ of the NiMo catalyst with 3 
wt \% USY loading at $290^{\circ} \mathrm{C}$ was $0.35 \mathrm{~h}^{-1}$, while the Pt catalyst had a rate constant of $0.89 \mathrm{~h}^{-1}$ at the same temperature. This shows that in the absence of $\mathrm{NH}_{3}$, the NiMo function was clearly insufficient to aliment all the acid sites, even for the lowest zeolite loading.

\section{Conclusions}

The data in this work confirm the very strong inhibition effect of $\mathrm{NH}_{3}$ on the hydroisomerization activity of bifunctional zeolites. By comparing the activity of Pt-USY- $\mathrm{Al}_{2} \mathrm{O}_{3}$ catalysts in the absence or presence of $\sim 0.05$ bar $\mathrm{NH}_{3}$, we could determine that less than $1 \%$ of the zeolite acid sites are active in catalysis in the presence of the inhibitor, even at $400^{\circ} \mathrm{C}$. At lower temperatures the inhibition effect is even much stronger (for example, only $0.01 \%$ of acid sites are vacant at $250^{\circ} \mathrm{C}$ ).

The presence of $\mathrm{NH}_{3}$ helps equilibrating the metal-acid balance, even if the activity loss caused by the inhibition of active sites is compensated by an increase in reaction temperature. This can be mathematically explained by the fact that the ratio of acid to metal activity evolves less quickly with temperature than the acid activity only.

Our work also provides a detailed comparison of the metal-acid balance in Pt and NiMo sulfide bifunctional catalysts. NiMo sulfide catalysts can be balanced only under two conditions, which both must be fulfilled: (i) The zeolite loading in the support must be low enough. (ii) An inhibitor of the acid sites $\left(\mathrm{NH}_{3}\right)$ must be present to shift the metal-acid balance in favor of the metal.

For NiMo sulfide catalysts with higher zeolite loading (higher acidity), the insufficient (de)hydrogenation activity of the sulfide phase leads to a drop in activity and a radical loss of selectivity to isomerization products, even in the presence of $\mathrm{NH}_{3}$ as inhibitor. 
When $\mathrm{NH}_{3}$ is absent, the reactivity pattern changes completely and cracking becomes the dominating reaction over isomerization.

\section{ACKNOWLEDGMENT}

The authors acknowledge V. Delattre and Ch. James for preparing and testing the Pt-catalysts.

\section{GLOSSARY}

$\Delta \mathrm{H}_{\mathrm{i}}=$ adsorption enthalpy of $\mathrm{i}$

$\mathrm{E}_{\mathrm{r}}=$ activation energy of the reaction $\mathrm{r}$

$\mathrm{k}=$ first order rate constant of the hydroconversion of $\mathrm{n}-\mathrm{C}_{16}$

$\mathrm{k}_{\mathrm{a}}=$ rate constant per acid site

$\mathrm{K}_{\mathrm{i}}=$ adsorption constant of $\mathrm{i}$

LHSV = Liquid Hourly Space Velocity

$\mathrm{m}_{\mathrm{i}}=$ mass fraction of compound $\mathrm{i}$

$\mathrm{n}_{\mathrm{acid} / \mathrm{metal}}=$ concentration of acid/metal sites

$\mathrm{p}_{\mathrm{i}}=$ partial pressure of $\mathrm{i}$

$\mathrm{X}=$ conversion on a mass percent basis

$\mathrm{Y}=$ yield on a mass percent basis

$\Theta_{i}=$ fractional coverage of $i$

\section{SUPPORTING INFORMATION}

The supporting information provides a more rigorous mathematical analysis of the effect of $\mathrm{NH}_{3}$ via the model of Degnan and Kennedy as well as additional Figures. This information is available free of charge via the Internet at http://pubs.acs.org/.

\section{AUTHOR INFORMATION}

\section{Corresponding Author}


Gerhard D. Pirngruber, Email: gerhard.pirngruber@ifpen.fr. IFP Energies nouvelles, Site of Lyon, BP3, 69360 Solaize, France.

\section{Present Addresses}

$\dagger$ TechnipFCM, Vaulx-en-Velin, France

\section{Author Contributions}

The manuscript was written through contributions of all authors. All authors have given approval to the final version of the manuscript.

\section{REFERENCES}

(1) Giannetto, G. E.; Perot, G. R.; Guisnet, M. R. Hydroisomerization and hydrocracking of n-alkanes. 1. Ideal hydroisomerization PtHY catalysts. Ind. Eng. Chem. Prod. Res. Dev. 1986, 25 (3), 481-490. DOI: 10.1021/i300023a021.

(2) Alvarez, F.; Ribeiro, F. R.; Perot, G.; Thomazeau, C.; Guisnet, M. Hydroisomerization and Hydrocracking of Alkanes 7. Influence of the Balance between Acid and Hydrogenating Functions on the Transformation of n-Decane on PtHY Catalysts. J. Catal. 1996, 162, 179-189.

(3) Weitkamp, J.; Ernst, S. Large pore molecular sieves. Catal. Today 1994, 19 (1), 107-149. DOI: 10.1016/0920-5861(94)85005-4.

(4) Weisz, P. B. Polyfunctional Heterogeneous Catalysis. Adv. Catal. 1962, 13, 137.

(5) Batalha, N.; Pinard, L.; Pouilloux, Y.; Guisnet, M. Bifunctional Hydrogenating/Acid Catalysis: Quantification of the Intimacy Criterion. Catal. Lett. 2013, 143 (6), 587-591. DOI: 10.1007/s10562-0131003-9.

(6) Batalha, N.; Pinard, L.; Bouchy, C.; Guillon, E.; Guisnet, M. n-Hexadecane hydroisomerization over PtHBEA catalysts. Quantification and effect of the intimacy between metal and protonic sites. J. Catal. 2013, 307, 122-131. DOI: 10.1016/j.jcat.2013.07.014.

(7) Zečević, J.; Vanbutsele, G.; de Jong, Krijn P; Martens, J. A. Nanoscale intimacy in bifunctional catalysts for selective conversion of hydrocarbons. Nature 2015, 528 (7581), 245-248.

(8) Cheng, K.; van der Wal, L. I.; Yoshida, H.; Oenema, J.; Harmel, J.; Zhang, Z.; Sunley, G.; Zečević, J.; Jong, K. P. de. Impact of the Spatial Organization of Bifunctional Metal-Zeolite Catalysts on the Hydroisomerization of Light Alkanes. Angew. Chem. Int. Ed. 2020, 59 (9), 3592-3600. DOI: 10.1002/anie.201915080.

(9) Noh, G.; Shi, Z.; Zones, S. I.; Iglesia, E. Isomerization and $\beta$-scission reactions of alkanes on bifunctional metal-acid catalysts: Consequences of confinement and diffusional constraints on reactivity and selectivity. J. Catal. 2018, 368, 389-410. DOI: 10.1016/j.jcat.2018.03.033. 
(10) Weitkamp, J. Catalytic Hydrocracking-Mechanisms and Versatility of the Process. ChemCatChem 2012, 4 (3), 292-306. DOI: 10.1002/cctc.201100315.

(11) Ribeiro, F.; Marcilly, C. Étude de la technique d'échange ionique avec compétition. Cas du dépôt de platine sur support solide acide par échange cationique. Oil Gas Sci. Tech. 1979, 34, 405-428.

(12) Roussel, M.; Lemberton, J. L.; Guisnet, M.; Cseri, T.; Benazzi, E. Mechanisms of n-decane hydrocracking on a sulfided NiW on silica-alumina catalyst. J. Catal. 2003, 218 (2), 427-437. DOI: 10.1016/S0021-9517(03)00164-7.

(13) Marcilly, C. Acido-basic catalysis; IFP publications, Ed. Technip: Paris, 2005.

(14) Bertoncini, F.; Bonduelle, A.; Francis, J.; Guillon, E. Hydrocracking. Toulhoat, Raybaud (Eds.), Catalysis by Transition Metal Sulfides, Ed. Technip, Paris, 2013; p 609.

(15) Galperin, L. B. Hydroisomerization of N-decane in the presence of sulfur and nitrogen compounds. Appl. Catal. A 2001, 209 (1-2), 257-268.

(16) Miller, S. J. Studies on Wax Isomerization for Lubes and Fuels. Stud. Surf. Sci. Catal. 1994, 84, 23192327.

(17) Batalha, N.; Astafan, A.; Dos Reis, J. Cavalcante; Pouilloux, Y.; Bouchy, C.; Guillon, E.; Pinard, L. Hydroisomerization of $n$-hexadecane over bifunctional Pt-HBEA catalysts. Influence of Si/Al ratio on activity selectivity. Reac Kinet Mech Cat 2015, 114 (2), 661-673. DOI: 10.1007/s11144-014-0794-z.

(18) Chica, A.; Diaz, U.; Fornés, V.; Corma, A. Changing the hydroisomerization to hydrocracking ratio of long chain alkanes by varying the level of delamination in zeolitic (ITQ-6) materials. Catal. Today 2009, 147 (3-4), 179-185. DOI: 10.1016/j.cattod.2008.10.046.

(19) Mehla, S.; Krishnamurthy, K. R.; Viswanathan, B.; John, M.; Niwate, Y.; Kumar, K.; Pai, S. M.; Newalkar, B. L. n-Hexadecane hydroisomerization over Pt/ZSM-12: Role of Si/Al ratio on product distribution. J. Porous Mater. 2013, 20 (5), 1023-1029.

(20) Merabti, R.; Pinard, L.; Lemberton, J. L.; Magnoux, P.; Barama, A.; Moljord, K. Effect of Na exchange of a HBEA zeolite on the activity and the selectivity of a bifunctional Pt-HBEA catalyst for $n$-hexadecane hydroisomerization. Comparison with a Pt-HZSM-22 catalyst. Reac. Kinet. Mech. Catal. 2010, 22, 33.

(21) Parmar, S.; Pant, K. K.; John, M.; Kumar, K.; Pai, S. M.; Gupta, S.; Newalkar, B. L. Hydroisomerization of $n$-hexadecane over Brønsted acid site tailored Pt/ZSM-12. J. Porous Mater. 2014, 21 (5), 849-857.

(22) Regali, F.; Boutonnet, M.; Järås, S. Hydrocracking of $n$-hexadecane on noble metal/silica-alumina catalysts. Catal. Today 2013, 214, 12-18. DOI: 10.1016/j.cattod.2012.10.019.

(23) Regali, F.; Liotta, L. F.; Venezia, A. M.; Montes, V.; Boutonnet, M.; Järås, S. Effect of metal loading on activity, selectivity and deactivation behavior of $\mathrm{Pd} /$ silica-alumina catalysts in the hydroconversion of n-hexadecane. Catal. Sci. Technol. 2014, 223, 87-96. DOI: 10.1016/j.cattod.2013.08.028.

(24) Wang, Y.; Tao, Z.; Wu, B.; Xu, J.; Huo, C.; Li, K.; Chen, H.; Yang, Y.; Li, Y. Effect of metal precursors on the performance of Pt/ZSM-22 catalysts for n-hexadecane hydroisomerization. J. Catal. 2015, 322, 1-13.

(25) Zhang, M.; Wang, L.; Chen, Y.; Zhang, Q.; Liang, C. Creating mesopores in ZSM-48 zeolite by alkali treatment: Enhanced catalyst for hydroisomerization of hexadecane. J. Energy Chem. 2016, 25 (3), 539544. DOI: 10.1016/j.jechem.2016.01.014.

(26) Zhang, S.; Chen, S.-L.; Dong, P.; Yuan, G.; Xu, K. Characterization and hydroisomerization performance of SAPO-11 molecular sieves synthesized in different media. Appl. Catal. A 2007, 332 (1), 46-55. DOI: 10.1016/j.apcata.2007.07.047. 
(27) Mendes, P. S. F.; Silva, J. M.; Ribeiro, M. F.; Duchêne, P.; Daudin, A.; Bouchy, C. Quantification of metal-acid balance in hydroisomerization catalysts: A step further toward catalyst design. AIChE J. 2017, 63 (7), 2864-2875. DOI: 10.1002/aic.15613.

(28) Mendes, P. S. F.; Silva, J. M.; Ribeiro, M. F.; Bouchy, C.; Daudin, A. Quantification of the available acid sites in the hydrocracking of nitrogen-containing feedstocks over USY shaped NiMo-catalysts. J. Ind. Eng. Chem. 2019, 71, 167-176. DOI: 10.1016/j.jiec.2018.11.019.

(29) Saint Laumer, J.-Y. de; Cicchetti, E.; Merle, P.; Egger, J.; Chaintreau, A. Quantification in Gas Chromatography: Prediction of Flame Ionization Detector Response Factors from Combustion Enthalpies and Molecular Structures. Anal. Chem. 2010, 82 (15), 6457-6462. DOI: 10.1021/ac1006574.

(30) Denayer, J.; Martens, J. A.; Jacobs, P. A.; Thybaut, J. W.; Marin, G. B.; Baron, G. V. Influence of the zeolite composition on the hydro-isomerisation and hydrocracking of alkanes on Pt/USY zeolites: Modelling of the reaction kinetics using an adsorption-reaction approach. Appl. Catal. A 2003, 246 (1), 17-28. DOI: 10.1016/S0926-860X(02)00665-8.

(31) Remy, M. J.; Stanica, D.; Poncelet, G.; Feijen, E. J. P.; Grobet, P. J.; Martens, J. A.; Jacobs, P. A. Dealuminated $\mathrm{H}-\mathrm{Y}$ Zeolites: Relation between Physicochemical Properties and Catalytic Activity in Heptane and Decane Isomerization. J. Phys. Chem. 1996, 100, 12440-12447.

(32) Mendes, P. S. F.; Gregorio, A. F. C.; Daudin, A.; Bouchy, C.; Silva, J. M.; Filipa Ribeiro, M. Elucidation of the zeolite role on the hydrogenating activity of Pt-catalysts. Catal. Comm. 2017, 89, 152-155. DOI: 10.1016/j.catcom.2016.11.006.

(33) Williams, B. A.; Babitz, S. M.; Miller, J. T.; Snurr, R. Q.; Kung, H. H. The roles of acid strength and pore diffusion in the enhanced cracking activity of steamed Y zeolites. Appl. Catal. A 1999, 177, 161175.

(34) Gounder, R.; Jones, A. J.; Carr, R. T.; Iglesia, E. Solvation and acid strength effects on catalysis by faujasite zeolites. J. Catal. 2012, 286, 214-223. DOI: 10.1016/j.jcat.2011.11.002.

(35) Bi, Y.; Xia, G.; Huang, W.; Nie, H. Hydroisomerization of long chain n-paraffins: the role of the acidity of the zeolite. RSC Adv 2015, 5 (120), 99201-99206.

(36) Thybaut, J. W.; Laxmi Narasimhan, C S; Denayer, J. F.; Baron, G.V.; Jacobs, P. A.; Martens, J. A.; Marin, G. B. Acid-Metal Balance of a Hydrocracking Catalyst: Ideal versus Nonideal Behavior. Ind. Eng. Chem. Res. 2005, 44, 5159-5169.

(37) Mendes, P. S. F.; Silva, J. M.; Filipa Ribeiro, M.; Daudin, A.; Bouchy, C. From powder to extrudate zeolite-based bifunctional hydroisomerization catalysts: On preserving zeolite integrity and optimizing $\mathrm{Pt}$ location. J. Ind. Eng. Chem. 2018, 62, 72-83. DOI: 10.1016/j.jiec.2017.12.046.

(38) Hanlon, R. T.; Kennedy, C. R.; Ware, R. A.; Wong, S. S. High Temperature Sensitivity of Paraffin Hydrocracking. Stud. Surf. Sci. Catal. 1993, 75, 2423-2426.

(39) Miller, S. J.; Lacheen, H. S.; Chen, C.-Y. Determining the Strength of Brønsted Acid Sites for Hydrodewaxing over Shape-Selective Catalysts. Ind. Eng. Chem. Res. 2016, 55 (24), 6760-6767.

(40) Suzuiki, K.; NODA, T.; Katada, N.; Niwa, M. IRMS-TPD of ammonia: Direct and individual measurement of Brønsted acidity in zeolites and its relationship with the catalytic cracking activity. $J$. Catal. 2007, 250 (1), 151-160. DOI: 10.1016/j.jcat.2007.05.024.

(41) Parillo, D. J.; Gorte, R. J. Characterization of Acidity in H-ZSM-5, H-ZSM-12, H-Mordenite, and H-Y Using Microcalorimetry. J. Phys. Chem. 1993, 97, 8786-8792. 
(42) Collignon, F.; Poncelet, G. Comparative Vapor Phase Synthesis of ETBE from Ethanol and Isobutene over Different Acid Zeolites. J. Catal. 2001, 202 (1), 68-77. DOI: 10.1006/jcat.2001.3280.

(43) Degnan, T. F.; Kennedy, C. R. Impact of catalyst acid/metal balance in hydroisomerization of normal paraffins. AlChE J. 1993, 39 (4), 607-614. DOI: 10.1002/aic.690390409.

(44) Mager-Maury, C.; Bonnard, G.; Chizallet, C.; Sautet, P.; Raybaud, P. H2-Induced Reconstruction of Supported Pt Clusters: Metal-Support Interaction versus Surface Hydride. ChemCatChem 2011, 3 (1), 200-207. DOI: 10.1002/cctc.201000324.

(45) Gautier, S.; Sautet, P. Coadsorption of Butadiene and Hydrogen on the (111) Surfaces of Pt and Pt 2 Sn Surface Alloy: Understanding the Cohabitation from First-Principles Calculations. J. Phys. Chem. C 2017, 121 (45), 25152-25163. DOI: 10.1021/acs.jpcc.7b07177.

(46) Zhu, J.; Yang, M.-L.; Yu, Y.; Zhu, Y.-A.; Sui, Z.-J.; Zhou, X.-G.; Holmen, A.; Chen, D. Size-Dependent Reaction Mechanism and Kinetics for Propane Dehydrogenation over Pt Catalysts. ACS Catal. 2015, 5 (11), 6310-6319.

(47) Spiewak, B. E.; Cortright, R. D.; Dumesic, J. A. Microcalorimetric Studies of H2, $\mathrm{C} 2 \mathrm{H} 4$, and $\mathrm{C} 2 \mathrm{H} 2$ Adsorption on Pt Powder. J. Catal. 1998, 176, 405-414.

(48) Noh, G.; Zones, S. I.; Iglesia, E. Consequences of Acid Strength and Diffusional Constraints for Alkane Isomerization and $\beta$-Scission Turnover Rates and Selectivities on Bifunctional Metal-Acid Catalysts. J. Phys. Chem. C 2018, 122 (44), 25475-25497. DOI: 10.1021/acs.jpcc.8b08460.

(49) Mendes, P. S. F.; Silva, J. M.; Ribeiro, F. H.; Daudin, A.; Bouchy, C. Bridging the gap between laboratory and industrial hydrocracking: on catalyst and operating conditions effects. Catal. Sci. Technol. 
TOC FIGURE

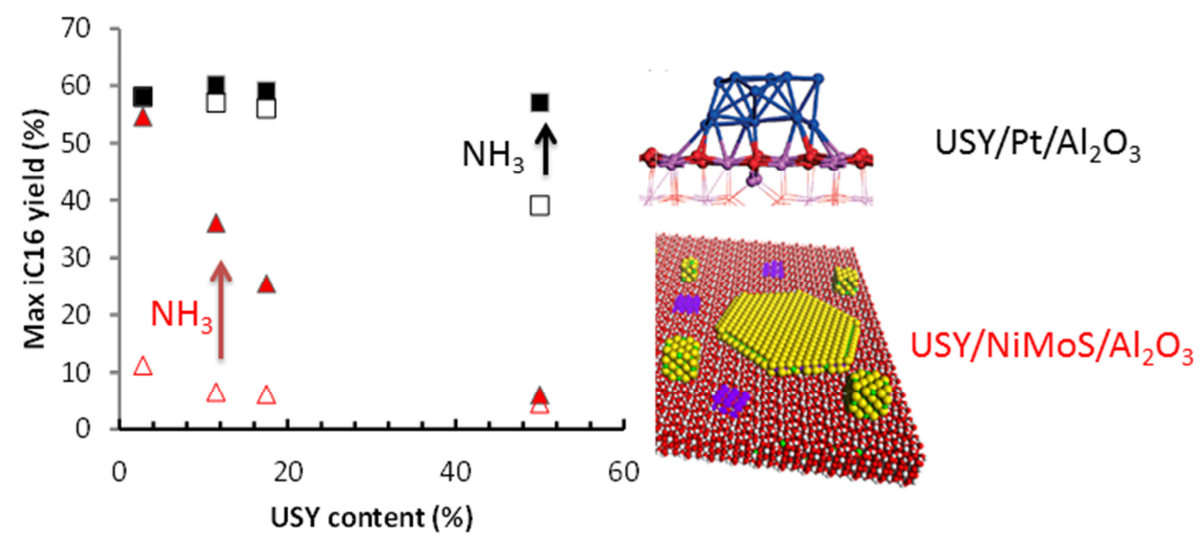

